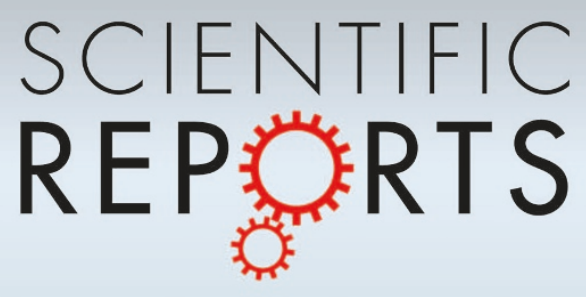

\title{
OPEN Micro-tubular solid oxide fuel cell based \\ on a porous yttria-stabilized zirconia \\ support
}

CONFERENCE PROCEEDINGS

APEnergy2014

..............

SUBJECT AREAS:

CHEMICAL

ENGINEERING

FUEL CELLS

MECHANICAL ENGINEERING

Received

28 February 2014

Accepted

10 June 2014

Published

29 August 2014

Correspondence and requests for materials should be addressed to

A.T. (a-tsu2mi@iis.utokyo.ac.jp)

\author{
Dhruba Panthi \& Atsushi Tsutsumi
}

Collaborative Research Center for Energy Engineering, Institute of Industrial Science, The University of Tokyo, 4-6-1 Komaba, Meguro-ku, Tokyo 153-8505, Japan.

Solid oxide fuel cells (SOFCs) are promising electrochemical energy conversion devices owing to their high power generation efficiency and environmentally benign operation. Micro-tubular SOFCs, which have diameters ranging from a few millimeters to the sub-millimeter scale, offer several advantages over competing SOFCs such as high volumetric power density, good endurance against thermal cycling, and flexible sealing between fuel and oxidant streams. Herein, we successfully realized a novel micro-tubular SOFC design based on a porous yttria-stabilized zirconia (YSZ) support using multi-step dip coating and co-sintering methods. The micro-tubular SOFC consisted of Ni-YSZ, YSZ, and strontium-doped lanthanum manganite (LSM)-YSZ as the anode, electrolyte, and cathode, respectively. In addition, to facilitate current collection from the anode and cathode, Ni and LSM were applied as an anode current collector and cathode current collector, respectively. Micro-crystalline cellulose was selected as a pore former to achieve better shrinkage behavior of the YSZ support so that the electrolyte layer could be densified at a co-sintering temperature of $1300^{\circ} \mathrm{C}$. The developed micro-tubular design showed a promising electrochemical performance with maximum power densities of 525,442 , and $354 \mathrm{~mW} \mathrm{~cm}{ }^{-2}$ at 850,800 , and $750^{\circ} \mathrm{C}$, respectively.

T he depletion of conventional fossil fuels coupled with the increasing amount of anthropogenic greenhouse gases in the earth's atmosphere has called for a move toward alternative energy sources and efficient energy utilization ${ }^{1-3}$. Solid oxide fuel cells (SOFCs), which convert chemical energy in hydrocarbon fuels directly into electricity, are regarded as the next generation of energy conversion devices owing to their high efficiency and low environmental impact ${ }^{4-7}$. Because SOFCs operate at a high temperature (typically $600-900^{\circ} \mathrm{C}$ ), their exhaust heat can be used for combined-cycle and cogeneration applications, thereby achieving significantly high system efficiencies $^{8-11}$. In addition to efficient power generation, reversible SOFCs have also shown promise for energy storage and fuel production from renewable electricity ${ }^{12-14}$. Although SOFCs were traditionally considered suitable only for stationary power generation due to their very high operating temperature $\left(\geq 900^{\circ} \mathrm{C}\right)$ and long start-up and shutdown times, recent developments in low-temperature SOFC materials and improved thermal shock resistance have made them attractive also for mobile and portable applications ${ }^{7}$. Moreover, a dramatic reduction in the electrolyte resistance as a result of nanometer-scale ultrathin electrolytes ${ }^{15,16}$ is expected to provide new opportunities for a broader range of SOFC applications.

Among the different geometric designs of SOFCs, the micro-tubular design offers a number of advantages. A tubular design alleviates issues associated with high-temperature sealing between fuel and oxidant streams because the seals can be placed out of the high-temperature zones. Since the active surface area per unit volume is inversely proportional to the cell diameter, micro-tubular SOFCs possess a significantly high volumetric power density. Additionally, their smaller size also reduces the thermal gradients, thereby making micro-tubular SOFCs robust against thermal cycling. Consequently, the start-up and shutdown times for a single micro-tubular SOFC can be as low as a few seconds. In view of these advantages, micro-tubular SOFCs have received increased attention in recent years ${ }^{17,18}$.

In a micro-tubular SOFC, structural support is usually provided by one of the active layers: electrolyte, anode, or cathode. Anode-supported designs have been pursued the most extensively owing to several favorable characteristics of the commonly used Ni-based cermet anodes such as good mechanical strength, relatively high electrical conductivity, and suitable properties for co-sintering with the electrolyte layer ${ }^{19-22}$. However, current collection from the inner electrode (i.e., bore side) of micro-tubular SOFCs has been identified to be a critical 
problem with any support component ${ }^{23-26}$. For the outer electrode, current can be tapped from the entire electrode surface using current collecting materials such as wires or meshes. However, due to the very small size of micro-tubular SOFCs, which ranges from a few millimeters to the sub-millimeter scale, the application of such current collectors is limited to only the exposed end/s of the inner electrode. This results in a longer current conduction path on the inner electrode side, thus increasing the ohmic resistance. This effect is more pronounced when the active cell length exceeds a few centimeters $^{23}$. To overcome this issue, we have proposed a novel microtubular design based on an inert support ${ }^{27}$. In this design, a thin current collecting layer is coated on top of the inert support so that current can be collected from the whole inner electrode surface. Computational fluid dynamics (CFD) simulations performed in our previous study ${ }^{28}$ showed that the proposed design results in a significantly reduced ohmic resistance and better performance even for longer cells with active lengths of several centimeters and above. In addition to providing a better current collection efficiency, the proposed design also minimizes issues related to the performance degradation of anode-supported micro-tubular SOFCs under redox cycle conditions $s^{29,30}$. In the present study, we successfully realized the proposed design by fabricating a micro-tubular SOFC with a porous yttria-stabilized zirconia (YSZ) support using an in-house developed multi-step dip coating method ${ }^{31}$. The micro-structural features of the fabricated cell were characterized by scanning electron microscope (SEM) and energy dispersive X-ray (EDX) images, and its electrochemical performance was evaluated using electrochemical impedance spectroscopy (EIS) and $I-V$ characteristic curves.

\section{Results}

The change in microstructure of the YSZ support and electrolyte layers with respect to the co-sintering temperature in the range $1250-1400^{\circ} \mathrm{C}$ is shown in Fig. 1 . When the co-sintering temperature increases, rapid growth of YSZ particles takes place due to the high sinterability of YSZ. As a result, the porosity of the support layer gradually decreases, thereby making it unsuitable for the diffusion of fuel gases. Conversely, an increased co-sintering temperature helps to achieve a perfectly dense electrolyte layer. Thus, it is important to carefully select the co-sintering temperature so that the support layer will retain its porosity and the electrolyte layer will be dense enough to prevent the gas crossover. Considering this fact, a co-sintering temperature of $1300^{\circ} \mathrm{C}$ was found to be optimum in the present study. The porosity and shrinkage of the pre-sintered YSZ support as functions of the co-sintering temperature are illustrated in Fig. 2. As shown, the support layer porosity was $37 \%$ for the sample cosintered at $1300^{\circ} \mathrm{C}$. This corresponded with a support layer shrinkage of ca. $19 \%$. Yamaguchi et al. ${ }^{32}$ previously showed that a minimum shrinkage of the support layer of ca. 15\% is necessary for obtaining a fully dense electrolyte layer. Thus, the shrinkage achieved for the YSZ support co-sintered at $1300^{\circ} \mathrm{C}$ was well above the minimum requirement. Additionally, it is to be noted that an open porosity of $35-40 \%$ is considered to be good enough for gaseous diffusion in SOFC components $^{33}$.

A cross-sectional view of a fractured half cell co-sintered at $1300^{\circ} \mathrm{C}$ is shown in Fig. 3a. The YSZ support tube had a homogeneous structure with an inner diameter of ca. $2.4 \mathrm{~mm}$ and an outer diameter of ca. $3.6 \mathrm{~mm}$. The fractured cross-section of a tested micro-tubular SOFC is illustrated in Fig. 3b. It can be seen that the different layers were well adhered to each other and the electrolyte layer was dense and free of pinholes. A close-up view of the cell cross-section and corresponding EDX mapping of $\mathrm{Ni}, \mathrm{Zr}$, and La elements are shown in Fig. 3c. The positions and thicknesses of the different layers are clearly distinguishable in the elemental distribution. The thicknesses of the Ni anode current collector, Ni-YSZ anode, YSZ electrolyte, strontium-doped lanthanum manganite (LSM)-YSZ cathode, and
LSM cathode current collector were estimated to be $12,10,18,6$, and $80 \mu \mathrm{m}$, respectively.

Impedance spectra for the single cell at different temperatures are shown in Fig. 4a. For each impedance spectrum, two distinct arcs can be observed: one at higher frequencies (on the left) and the other at lower frequencies (on the right). It is to be noted that high-frequency intercepts in the impedance spectra were not observed due to the frequency limitation (upper limit of $20 \mathrm{kHz}$ ) of the impedance meter. An equivalent circuit with $R_{\mathrm{ohm}}+R_{1}\left\|Q_{1}+R_{2}\right\| Q_{2}$ configuration (Fig. 4b) was used to fit these impedance spectra. $R_{\mathrm{ohm}}$ represents ohmic resistance contributed by the cell components. $R_{1} \| Q_{1}$ and $R_{2} \| Q_{2}$ represent the high-frequency and low-frequency arcs, respectively, where $R$ is the resistance and $Q$ the constant phase element $(\mathrm{CPE})$ of the corresponding arcs. The high-frequency resistance $\left(R_{1}\right)$ and the low-frequency resistance $\left(R_{2}\right)$ are attributed to activation and concentration polarization losses, respectively ${ }^{20,22,31,34}$. The contribution of different resistances to the total cell resistance at different temperatures is given in Table 1.

Figure 5 shows plots of voltage and power density versus the current density of the single cell. The open-circuit voltages (OCVs) obtained at 850,800 , and $750^{\circ} \mathrm{C}$ were $1.035,1.046$, and 1.057 , respectively. These values, close to the theoretical ones, confirmed that the chosen co-sintering temperature $\left(1300^{\circ} \mathrm{C}\right)$ was high enough for a gas-tight electrolyte layer to be achieved, as also indicated by the SEM micrographs in Fig. 3. The maximum power densities generated by the cell were 525,442 , and $354 \mathrm{~mW} \mathrm{~cm}^{-2}$ at 850,800 , and $750^{\circ} \mathrm{C}$, respectively.

\section{Discussion}

The shrinkage behavior of the support layer is an important consideration for the fabrication of micro-tubular SOFCs. It plays a crucial role in determining the co-sintering temperature at which the electrolyte layer is fully densified, which successively affects the manufacturing steps involved and the microstructural characteristics of each layer. There are several factors responsible for the shrinkage behavior of the support layer such as pre-sintering temperature, type of pore former used, and the support layer material itself. The excellent shrinkage of the YSZ support in the present study can be attributed to the use of micro-crystalline cellulose as the pore former. Compared with other pore formers such as graphite and polymethyl methacrylate (PMMA), cellulose is known to cause better shrinkage of the support tube because of its ability to expand by absorbing the solvents during the slurry preparation process ${ }^{35}$. Thus, the use of the cellulose pore former made it possible to lower the co-sintering temperature to $1300^{\circ} \mathrm{C}$ from the typical range of $1400-1500^{\circ} \mathrm{C}$, which in turn helped to maintain the porosity of the YSZ support.

Compatibility among different SOFC components depends on the manufacturing methods used as well as their thermal, chemical, and mechanical properties. In the developed micro-tubular design, the contact between the YSZ support layer and the Ni current collector layer was of particular importance because there is an appreciable difference between the coefficients of thermal expansion (CTEs) of the two materials $\left(13.3 \times 10^{-6} \mathrm{~K}^{-1}\right.$ for $\mathrm{Ni}$ and $10.5 \times 10^{-6} \mathrm{~K}^{-1}$ for $\mathrm{YSZ}$ at $\left.1000^{\circ} \mathrm{C}\right)^{36}$, and poor contact between them may affect structural integrity of the whole cell. From the microstructural observations above, it is evident that the manufacturing method employed was effective in achieving a homogeneous and well-connected SOFC structure. A particular concern may arise regarding the long-term stability of the cell due to the grain growth and coarsening of $\mathrm{Ni}$ particles in both the anode and its current collector layer. However, these effects can be suppressed by adding low surface energy oxides to $\mathrm{Ni} / \mathrm{Ni}$-YSZ as well as through proper microstructure tailoring of these layers ${ }^{37}$.

The impedance spectra for the micro-tubular SOFC showed that the contribution of the ohmic resistance to the total cell resistance was very small due to improved current collection from both the 

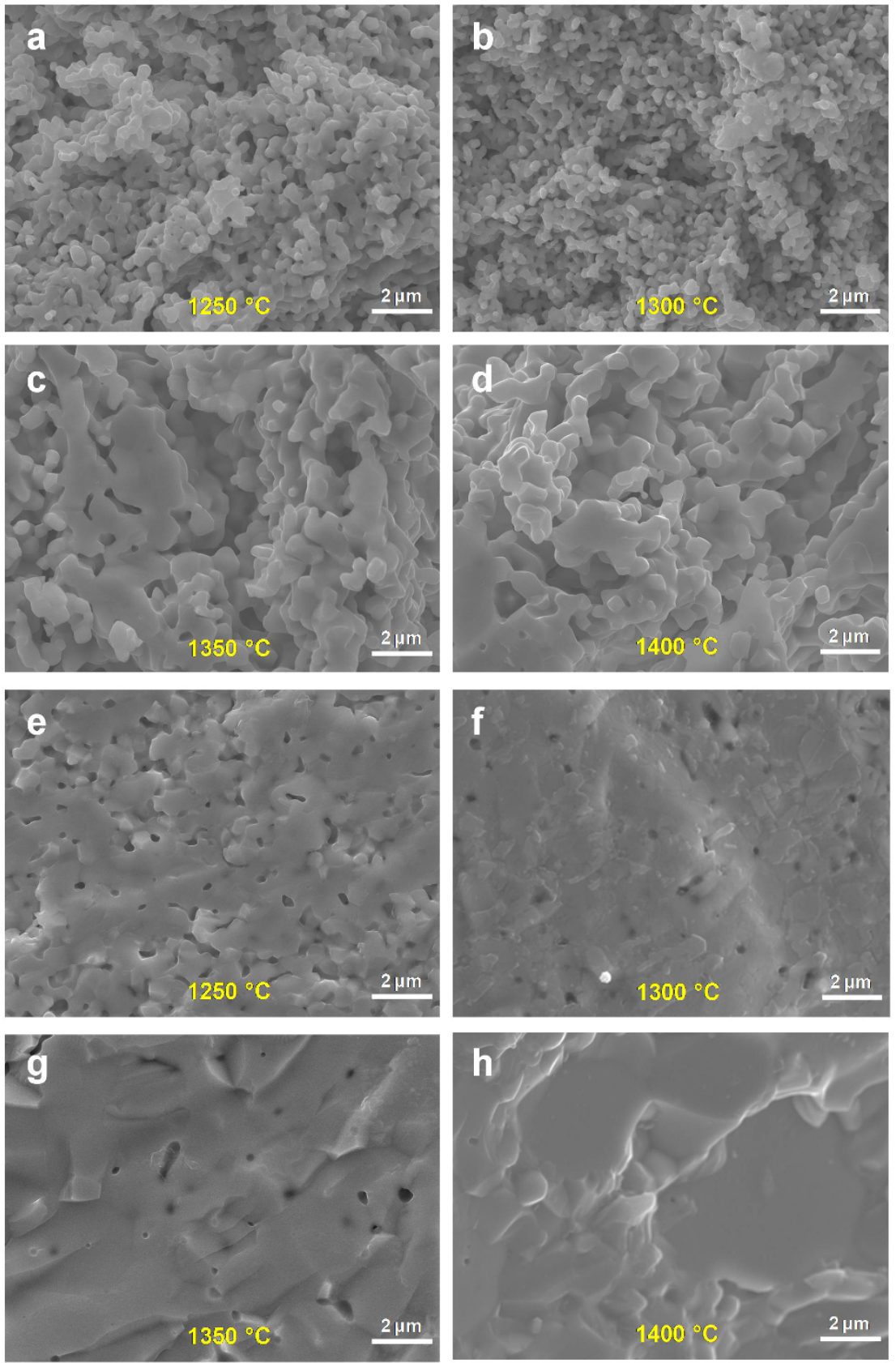

Figure $1 \mid$ Cross-sectional SEM micrographs showing YSZ support and electrolyte microstructures at different co-sintering temperatures. (a-d) Support microstructure. $(\mathrm{e}-\mathrm{h})$ Electrolyte microstructure.

electrodes. As listed in Table 1, the ohmic resistance was 0.043, 0.061, and $0.078 \Omega \mathrm{cm}^{2}$ at 850,800 , and $750^{\circ} \mathrm{C}$, respectively. These values are close to the resistance of the YSZ electrolyte with the present thickness of $18 \mu \mathrm{m}$ at the respective temperatures ${ }^{38}$. However, the concentration polarization of the cell was found to be relatively high despite a good porosity of the YSZ support layer. There could be a couple of possible reasons for the high concentration polarization. To ensure good mechanical strength of the cell, the YSZ support layer had a thickness of ca. $600 \mu \mathrm{m}$, which is fairly large compared to a thickness of 200-300 $\mu \mathrm{m}$ for the commonly used anode supports. The thick YSZ support may have resulted in a poor diffusion of gaseous species. In addition, it is likely that the diffusion of the gaseous species through the $\mathrm{Ni}$ current collector and Ni-YSZ anode layers also considerably added to the total concentration polarization, as indicated by the close-up views of their microstructures in Fig. 6. It is well known that the concentration polarization of anode- supported micro-tubular SOFCs is largely influenced by the anode microstructure ${ }^{22}$. In the present micro-tubular SOFC, both the $\mathrm{Ni}$ current collector and Ni-YSZ anode layers showed rather low porosity since their porosity was derived mainly from the reduction of $\mathrm{NiO}$ particles to $\mathrm{Ni}$ during electrochemical testing. Therefore, the microstructure optimization of these two layers seems to be important for minimizing the concentration losses. On the other hand, the activation polarization was observed to increase notably with decreasing operating temperature owing to the reduced electrocatalytic properties of the electrode materials, mainly the LSM-YSZ cathode $^{39}$. Moreover, the LSM-YSZ cathode thickness $(6 \mu \mathrm{m})$ is likely to have been rather small for high oxygen reduction activity. Although most of the LSM-YSZ cathode performance is achieved at a thickness as low as $2 \mu \mathrm{m}$, the resistance associated with YSZ grain boundaries has been found to be reduced with the increased cathode thickness ${ }^{40}$. Thus, the optimization of the LSM-YSZ cathode thick- 


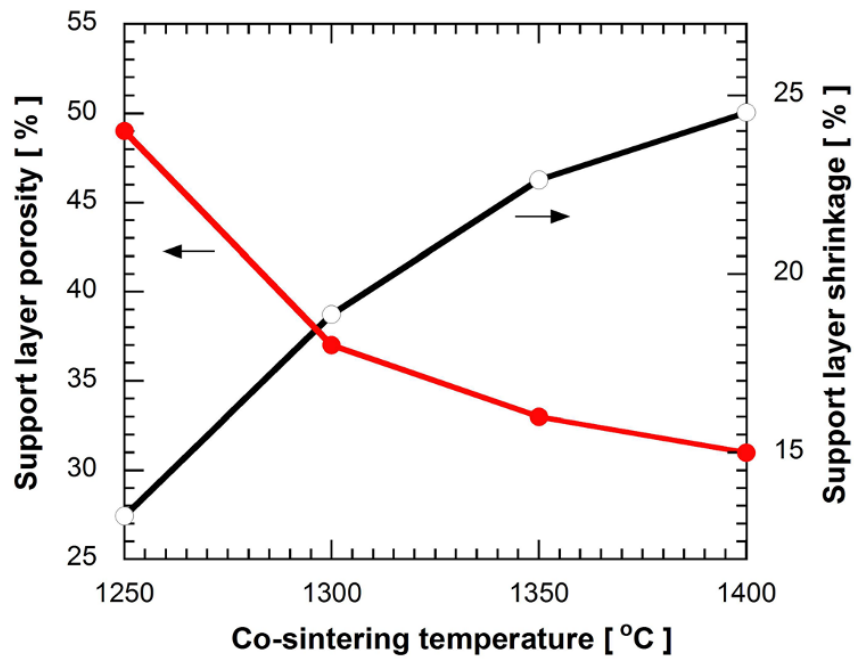

Figure 2 | Variation of porosity and shrinkage of pre-sintered YSZ support with the co-sintering temperature. ness may play a role in lowering down the activation polarization to some extent.

Despite the above limitations, the micro-tubular SOFC showed promising power generation characteristics. The power densities obtained in the present study are comparable to those observed for anode-supported micro-tubular SOFCs with similar component materials and active cell lengths ${ }^{20,31,41}$. In addition, the maximum power density at $800^{\circ} \mathrm{C}\left(442 \mathrm{~mW} \mathrm{~cm}^{-2}\right)$ was $31 \%$ higher than that of a tubular SOFC with a similar cell structure but with materials more favorable for intermediate temperature range $\left(600-800^{\circ} \mathrm{C}\right)^{30}$. The better electrochemical performance of the present micro-tubular SOFC despite the use of all conventional materials is attributable to its significantly low ohmic and concentration polarization resistances compared to those of the cell reported in ref. 30 .

In summary, a novel micro-tubular SOFC with a configuration of YSZ/Ni/Ni-YSZ/YSZ/LSM-YSZ/LSM was successfully fabricated using multi-step dip coating and co-sintering methods. The porosity of the YSZ support was maintained at $37 \%$ by adding micro-crystalline cellulose as a pore former and reducing the co-sintering temperature to $1300^{\circ} \mathrm{C}$. With humidified $\mathrm{H}_{2}$ as the fuel and ambient air as the oxidant, the micro-tubular SOFC generated maximum power
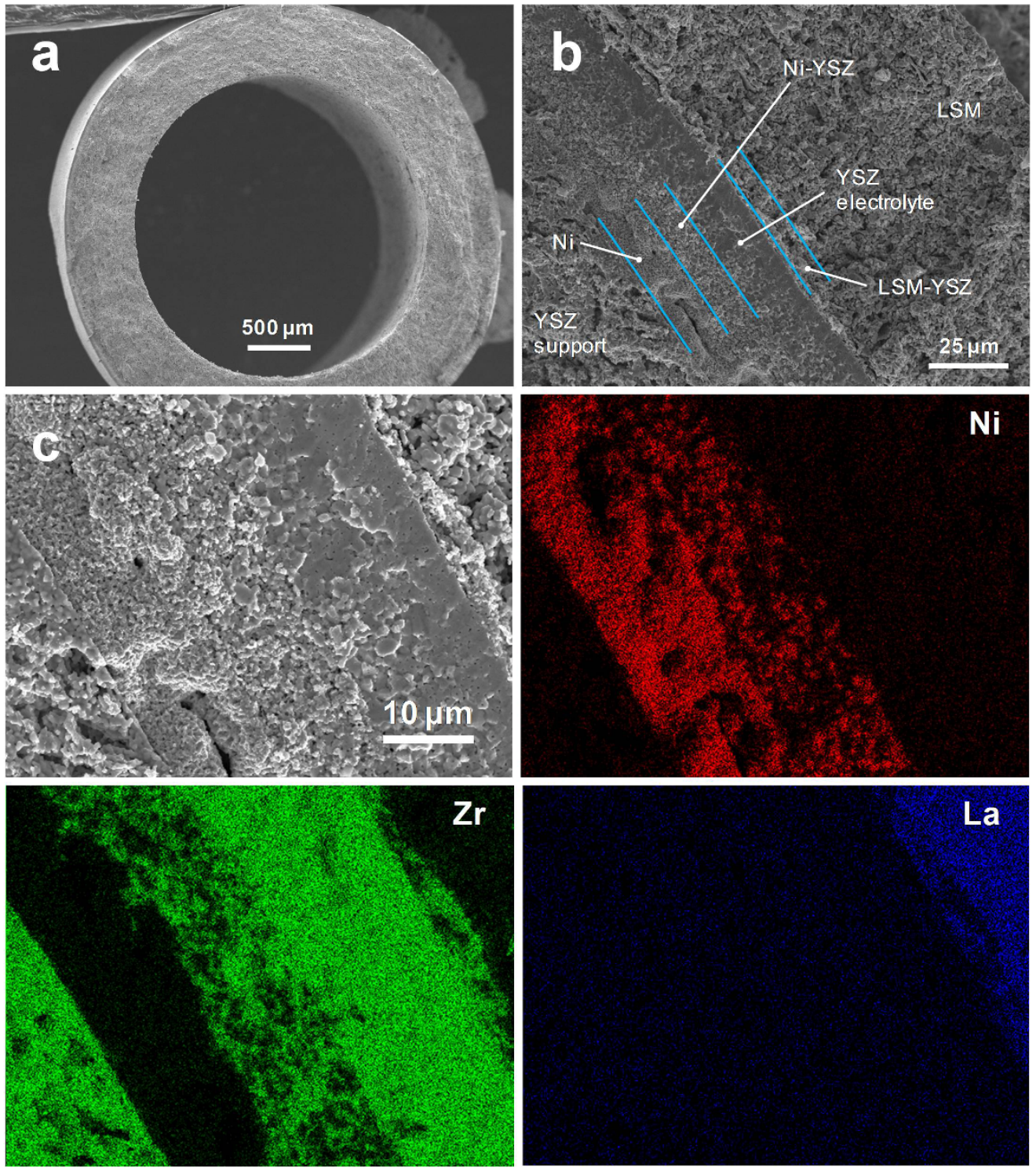

Figure $3 \mid$ Cross-sectional SEM and EDX micrographs. (a) Half cell co-sintered at $1300^{\circ} \mathrm{C}$. (b) Full cell after electrochemical testing. (c) Close-up view of (b) and elemental distribution of $\mathrm{Ni}, \mathrm{Zr}$ and $\mathrm{La}$. 
a

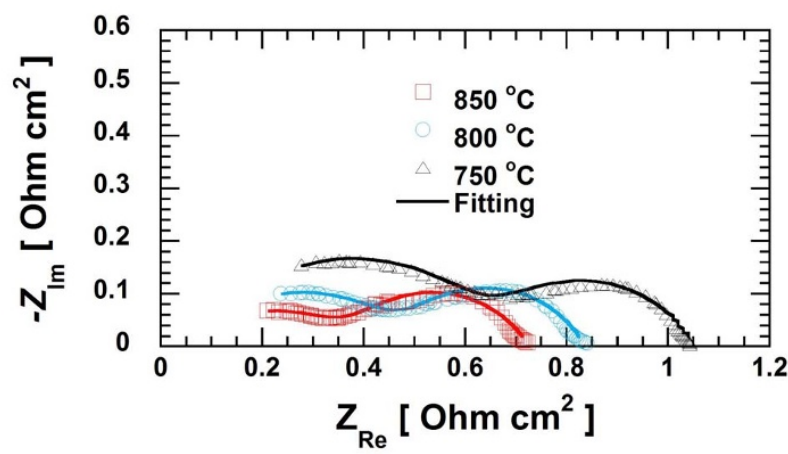

b

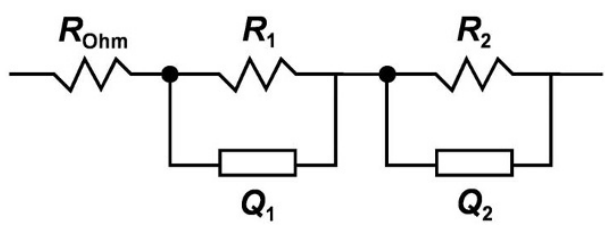

Figure $4 \mid$ (a) Impedance spectra for single cell. (b) Equivalent circuit used to fit the impedance spectra.

densities of 525,442 , and $354 \mathrm{~mW} \mathrm{~cm}^{-2}$ at 850,800 , and $750^{\circ} \mathrm{C}$, respectively. These power densities are comparable to those of the conventional anode-supported micro-tubular SOFCs with similar component materials and active cell lengths. However, as suggested by the simulation study ${ }^{28}$, the present micro-tubular design could be expected to deliver a distinctly better performance for longer cells with active lengths exceeding several centimeters, where conventional designs suffer from the high ohmic loss associated with current collection from the inner electrode.

\section{Methods}

A YSZ support slurry was prepared by mixing $48 \mathrm{wt} \%$ YSZ (TZ-8Y, Tosoh Corp., Yamaguchi, Japan) and $12 \mathrm{wt} \%$ micro-crystalline cellulose (Avicel, Merck, Darmstadt, Germany) powders in a binary solvent of toluene and ethanol and ballmilling the mixture for $24 \mathrm{~h}$. Polyvinyl butyral (PVB; Sigma Aldrich, St. Louis, USA), tallow propylene diamine (Diamin RRT, Kao Corp., Tokyo, Japan), and dioctyl phthalate (DOP; Sigma Aldrich) were used as binder, dispersant, and plasticizer, respectively. The same solvents and organic additives were used for the other slurries. The YSZ support slurry was dip coated on a carbon rod $(\varnothing 3 \mathrm{~mm}$, length $40 \mathrm{~mm})$ at a pulling rate of $2 \mathrm{~mm} \mathrm{~s}^{-1}$ several times until a desired thickness of the YSZ support layer was achieved. Each dip coating was followed by drying at $80^{\circ} \mathrm{C}$ for $5-10 \mathrm{~min}$ to remove the solvents. A NiO slurry was dip coated on top of the YSZ support as an anode current collector. The $\mathrm{NiO}$ slurry consisted of $27 \mathrm{wt} \% \mathrm{NiO}$ (NiO-AFL, Kceracell, Kumsan-Kun, South Korea) and 1.5 wt\% micro-crystalline cellulose. The YSZ/NiO bilayer was pre-sintered in air at $1000^{\circ} \mathrm{C}$ for $1 \mathrm{~h}$ using a heating profile discussed in our previous paper ${ }^{31}$.

Next, an anode slurry composed of $18 \mathrm{wt} \% \mathrm{NiO}$ and $12 \mathrm{wt} \% \mathrm{YSZ}$ was dip coated onto the pre-sintered $\mathrm{YSZ} / \mathrm{NiO}$ bilayer and the sample was dried at $80^{\circ} \mathrm{C}$ for $1 \mathrm{~h}$. This was followed by dip coating of an electrolyte slurry containing $30 \mathrm{wt} \% \mathrm{YSZ}$. The sample was then co-sintered in air at temperatures ranging from 1250 to $1400^{\circ} \mathrm{C}$ for $3 \mathrm{~h}$ at a heating rate of $5^{\circ} \mathrm{C} \mathrm{min}^{-1}$. LSM-YSZ and LSM slurries were dip coated onto a half cell co-sintered at $1300^{\circ} \mathrm{C}$ as a cathode and cathode current collector, respectively. The LSM-YSZ slurry was prepared by mixing $20 \mathrm{wt} \%$ LSM (LSM-80F, Daiichi Kigenso Kagaku Kogyo, Osaka, Japan) and 20 wt\% YSZ, whereas the LSM slurry

Table 1 Area-specific resistance values obtained from impedance spectra for single cell

\begin{tabular}{llll} 
& $850^{\circ} \mathrm{C}$ & $800^{\circ} \mathrm{C}$ & $750^{\circ} \mathrm{C}$ \\
\hline$R_{\text {ohm }}\left(\Omega \mathrm{cm}^{2}\right)$ & 0.043 & 0.061 & 0.078 \\
$R_{1}\left(\Omega \mathrm{cm}^{2}\right)$ & 0.339 & 0.419 & 0.573 \\
$R_{2}\left(\Omega \mathrm{cm}^{2}\right)$ & 0.345 & 0.357 & 0.401 \\
Total cell resistance $\left(\Omega \mathrm{cm}^{2}\right)$ & 0.727 & 0.837 & 1.052 \\
\hline
\end{tabular}

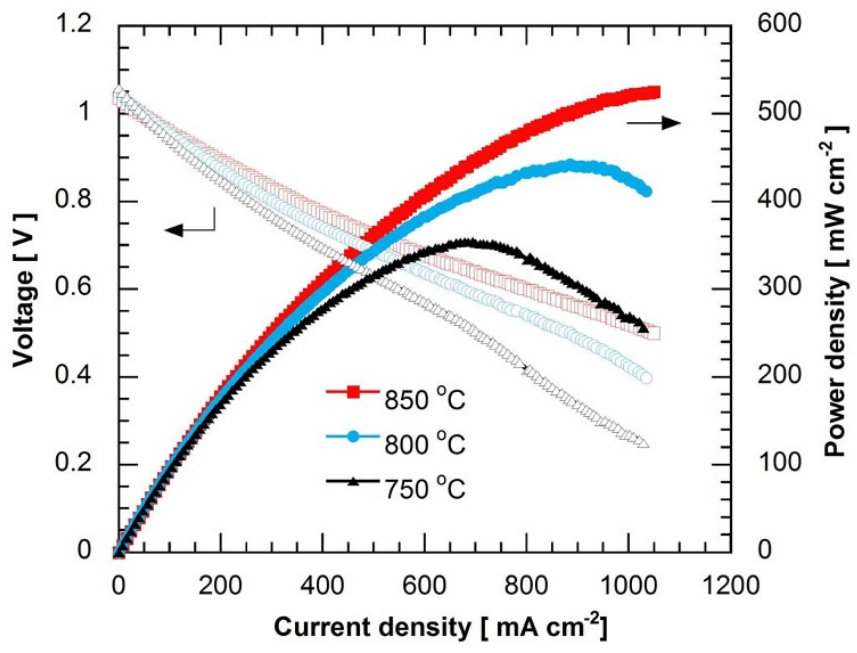

Figure 5 | Power generation characteristics for single cell.

consisted of $40 \mathrm{wt} \% \mathrm{LSM}$. The sample was finally sintered in air at $1150^{\circ} \mathrm{C}$ for $1 \mathrm{~h}$ at a heating rate of $5^{\circ} \mathrm{C} \mathrm{min}^{-1}$. The active cathode length of the sample was $10 \mathrm{~mm}$.

The electrochemical performance was evaluated by heating the micro-tubular SOFC sample in an electric furnace at three different temperatures: 850,800 , and $750^{\circ} \mathrm{C}$. The sample was connected to the fuel supply tube with an alumina-based adhesive (Ceramabond 552, Aremco Products, NY, USA). The anodic and cathodic currents were collected using platinum wires as the current leads with platinum paste applied over the electrode surfaces for better electrical contact. Humidified $\mathrm{H}_{2}(3 \%$ $\mathrm{H}_{2} \mathrm{O}$ ) at a flow rate of $20 \mathrm{~cm}^{3} \mathrm{~min}^{-1}$ and ambient air at a flow rate of $20,000 \mathrm{~cm}^{3}$ $\mathrm{min}^{-1}$ were used as the fuel and oxidant, respectively. The corresponding fuel utilization was estimated to be ca. 27 to $41 \%{ }^{18}$. The $\mathrm{NiO}$ in the anode was reduced to Ni by exposing the sample to $\mathrm{H}_{2}$ for $30 \mathrm{~min}$ at $850^{\circ} \mathrm{C}$ before conducting the electrochemical measurements.

$I-V$ characteristic curves were obtained by varying the load current with an electronic load device (PLZ664WA, Kikusui Electronics Corp., Yokohama, Japan). EIS
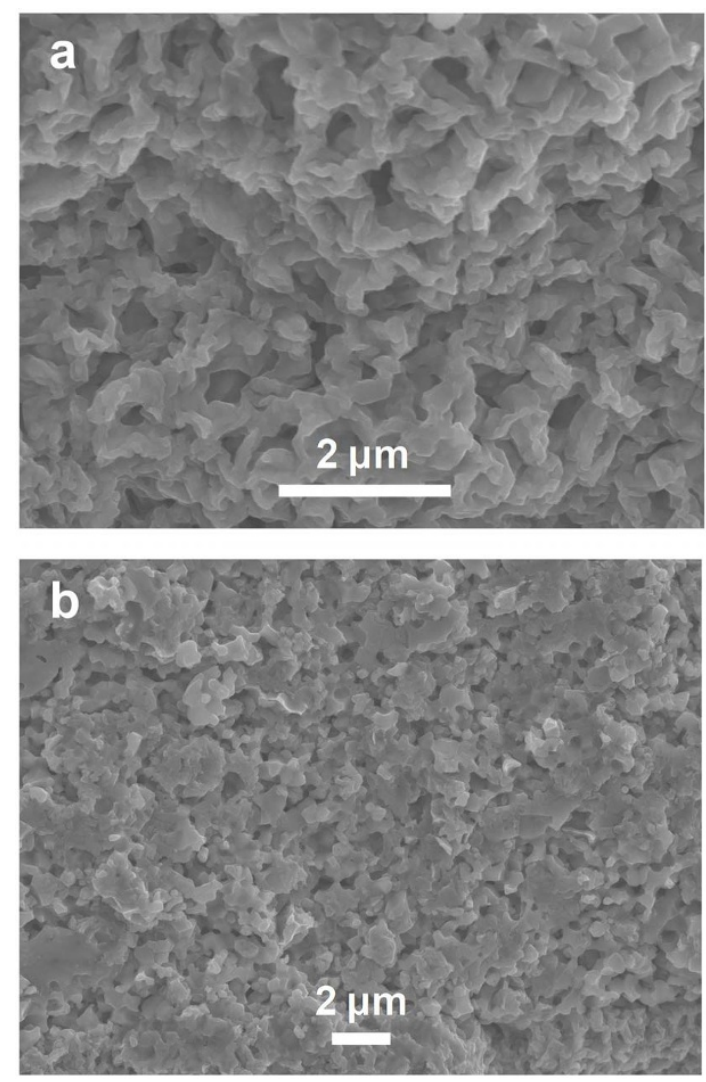

Figure 6 | Close-up views of (a) Ni current collector microstructure and (b) Ni-YSZ anode microstructure. 
measurements were performed using an impedance meter (KFM2150, Kikusui Electronics Corp.) in the frequency range from $20 \mathrm{kHz}$ to $200 \mathrm{mHz}$ under a load current of $100 \mathrm{~mA} \mathrm{~cm}^{-2}$ and an AC perturbation of $10 \mathrm{~mA} \mathrm{~cm} \mathrm{~cm}^{-2}$

An SEM equipped with an EDX analyzer (JSM-7001F, JEOL, Tokyo, Japan) was used to examine the SOFC microstructures. The porosity of the YSZ supports were determined by Archimedes' method with deionized water as the immersion medium.

1. Dresselhaus, M. S. \& Thomas, I. L. Alternative energy technologies. Nature 414, 332-337 (2001).

2. Omer, A. M. Energy, environment and sustainable development. Renew. Sustain. Energy Rev. 12, 2265-2300 (2008).

3. Kang, C. et al. Carbon Emission Flow in Networks. Sci. Rep. 2, 479 (2012)

4. Singhal, S. C. Advances in solid oxide fuel cell technology. Solid State Ionics 135, 305-313 (2000).

5. Steele, B. C. H. \& Heinzel, A. Materials for fuel-cell technologies. Nature 414, 345-352 (2001).

6. Minh, N. Q. Solid oxide fuel cell technology - features and applications. Solid State Ionics 174, 271-277 (2004)

7. Wachsman, E. D. \& Lee, K. T. Lowering the Temperature of Solid Oxide Fuel Cells. Science 334, 935-939 (2011).

8. Kuchonthara, P., Bhattacharya, S. \& Tsutsumi, A. Combinations of solid oxide fuel cell and several enhanced gas turbine cycles. J. Power Sources 124, 65-75 (2003).

9. Kuchonthara, P., Bhattacharya, S. \& Tsutsumi, A. Combination of thermochemical recuperative coal gasification cycle and fuel cell for power generation. Fuel 84, 1019-1021 (2005).

10. Shao, Z. et al. Electric Power and Synthesis Gas Co-generation From Methane with Zero Waste Gas Emission. Angew. Chem. 123, 1832-1837 (2011).

11. Choudhury, A., Chandra, H. \& Arora, A. Application of solid oxide fuel cell technology for power generation-A review. Renew. Sustain. Energy Rev. 20, 430-442 (2013).

12. Bierschenk, D. M., Wilson, J. R. \& Barnett, S. A. High efficiency electrical energy storage using a methane-oxygen solid oxide cell. Energy Environ. Sci. 4, 944-951 (2011)

13. Ruiz-Morales, J. C., Marrero-López, D., Canales-Vázquez, J. \& Irvine, J. T. S. Symmetric and reversible solid oxide fuel cells. RSC Adv. 1, 1403-1414 (2011).

14. Minh, N. Q. \& Mogensen, M. B. Reversible Solid Oxide Fuel Cell Technology for Green Fuel and Power Production. Electrochem. Soc. Interface 22, 55-62 (2013).

15. Kerman, K., Lai, B. K. \& Ramanathan, S. Pt/ $\mathrm{Y}_{0.16} \mathrm{Zr}_{0.84} \mathrm{O}_{1.92} / \mathrm{Pt}$ thin film solid oxide fuel cells: Electrode microstructure and stability considerations. J. Power Sources 196, 2608-2614 (2011).

16. Motoyama, M. et al. Nanotubular array solid oxide fuel cell. ACS Nano 8, 340-351 (2014).

17. Lawlor, V. et al. Review of the micro-tubular solid oxide fuel cell: Part I. Stack design issues and research activities. J. Power Sources 193, 387-399 (2009).

18. Howe, K. S., Thompson, G. J. \& Kendall, K. Micro-tubular solid oxide fuel cells and stacks. J. Power Sources 196, 1677-1686 (2011).

19. Sarkar, P., Yamarte, L., Rho, H. \& Johanson, L. Anode-Supported Tubular MicroSolid Oxide Fuel Cell. Int. J. Appl. Ceram. Technol. 4, 103-108 (2007).

20. Shikazono, N., Sakamoto, Y., Yamaguchi, Y. \& Kasagi, N. Microstructure and polarization characteristics of anode supported tubular solid oxide fuel cell with co-precipitated and mechanically mixed Ni-YSZ anodes. J. Power Sources 193, 530-540 (2009).

21. Zhang, L. et al. Fabrication and Characterization of Anode-Supported Tubular Solid-Oxide Fuel Cells by Slip Casting and Dip Coating Techniques. J. Am. Ceram. Soc. 92, 302-310 (2009).

22. Suzuki, T. et al. Impact of Anode Microstructure on Solid Oxide Fuel Cells. Science 325, 852-855 (2009).

23. Suzuki, T., Yamaguchi, T., Fujishiro, Y. \& Awano, M. Current collecting efficiency of micro tubular SOFCs. J. Power Sources 163, 737-742 (2007).

24. Virkar, A. V., Lange, F. F. \& Homel, M. A. A simple analysis of current collection in tubular solid oxide fuel cells. J. Power Sources 195, 4816-4825 (2010).

25. Droushiotis, N., Doraswami, U., Kelsall, G. H. \& Li, K. Micro-tubular solid oxide fuel cells fabricated from hollow fibres. J. Appl. Electrochem. 41, 1005-1012 (2011)
26. De la Torre, R., Avila-Paredes, H. J. \& Sglavo, V. M. Comparative Performance Analysis of Anode-Supported Micro-Tubular SOFCs with Different CurrentCollection Architectures. Fuel Cells 13, 729-732 (2013).

27. Panthi, D., Choi, B. \& Tsutsumi, A. A novel type of micro-tubular SOFC for application in super IGFC system. in: Proc. Int. Symp. Chem. React. Eng. Maastricht, 2012

28. Panthi, D. \& Tsutsumi, A. Development of a High-Performance Micro-Tubular SOFC Based on a Hollow Fiber Support. ECS Trans. 57, 789-798 (2013).

29. Heo, Y.-H. et al. Redox-induced performance degradation of anode-supported tubular solid oxide fuel cells. Int. J. Hydrogen Energy 36, 797-804 (2011).

30. Zhao, K., Kim, B.-H., Xu, Q. \& Ahn, B.-G. Fabrication and characterization of inert-substrate-supported tubular single cells by dip-coating process. J. Power Sources 245, 671-677 (2014).

31. Panthi, D. \& Tsutsumi, A. A novel multistep dip-coating method for the fabrication of anode-supported microtubular solid oxide fuel cells. J. Solid State Electrochem. 18, 1899-1905 (2014).

32. Yamaguchi, T., Suzuki, T., Shimizu, S., Fujishiro, Y. \& Awano, M. Examination of wet coating and co-sintering technologies for micro-SOFCs fabrication. J. Membr. Sci. 300, 45-50 (2007).

33. Mingyi, L., Bo, Y., Jingming, X. \& Jing, C. Influence of pore formers on physical properties and microstructures of supporting cathodes of solid oxide electrolysis cells. Int. J. Hydrogen Energy 35, 2670-2674 (2010).

34. Barfod, R. et al. Detailed characterization of anode-supported SOFCs by impedance spectroscopy. J. Electrochem. Soc. 154, B371-B378 (2007)

35. Suzuki, T., Yamaguchi, T., Hamamoto, K., Sumi, H. \& Fujishiro, Y. Low temperature densification process of solid-oxide fuel cell electrolyte controlled by anode support shrinkage. RSC Adv. 1, 911-916 (2011).

36. Goodenough, J. B. \& Huang, Y.-H. Alternative anode materials for solid oxide fuel cells. J. Power Sources 173, 1-10 (2007).

37. Zhu, W. Z. \& Deevi, S. C. A review on the status of anode materials for solid oxide fuel cells. Mater. Sci. Eng. A 362, 228-239 (2003).

38. Han, M., Tang, X., Yin, H. \& Peng, S. Fabrication, microstructure and properties of a YSZ electrolyte for SOFCs. J. Power Sources 165, 757-763 (2007).

39. Ivers-Tiffée, E., Weber, A. \& Herbstritt, D. Materials and technologies for SOFCcomponents. J. Eur. Ceram. Soc. 21, 1805-1811 (2001).

40. Murray, E. P., Tsai, T. \& Barnett, S. A. Oxygen transfer processes in (La,Sr) $\mathrm{MnO}_{3} /$ $\mathrm{Y}_{2} \mathrm{O}_{3}$-stabilized $\mathrm{ZrO}_{2}$ cathodes: an impedance spectroscopy study. Solid State Ionics 110, 235-243 (1998).

41. Yang, C. et al. Fabrication and characterization of an anode-supported hollow fiber SOFC. J. Power Sources 187, 90-92 (2009).

\section{Acknowledgments}

The authors gratefully acknowledge financial support from the Japan Society for the Promotion of Science (JSPS) in the form of a Grant-in-Aid for Scientific Research (number 23360434).

\section{Author contributions}

D.P. and A.T. conceptualized the study and planned the experiments. D.P. performed the experiments. D.P. and A.T. discussed the results and prepared the manuscript.

\section{Additional information}

Competing financial interests: The authors declare no competing financial interests.

How to cite this article: Panthi, D. \& Tsutsumi, A. Micro-tubular solid oxide fuel cell based on a porous yttria-stabilized zirconia support. Sci. Rep. 4, 5754; DOI:10.1038/srep05754 (2014)

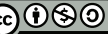

This work is licensed under a Creative Commons Attribution-NonCommercialShareAlike 4.0 International License. The images or other third party material in this article are included in the article's Creative Commons license, unless indicated otherwise in the credit line; if the material is not included under the Creative Commons license, users will need to obtain permission from the license holder in order to reproduce the material. To view a copy of this license, visit http:// creativecommons.org/licenses/by-nc-sa/4.0/ 